\title{
Civic Literasi Bijak Dalam Bermedia Sosial Bagi Ibu-Ibu PKK Kecamatan Banjarsari Kota Surakarta
}

\author{
Rima Vien Permata Hartanto ${ }^{1,}$, Triyanto $^{2,}$ Erna Yuliandari ${ }^{3,}$ Yudi Ariana ${ }^{4}$ \\ 1,2,3,4 Program Studi Pendidikan Pancasila dan Kewarganegaraan \\ FKIP Universitas Sebelas Maret Surakarta \\ Email : rimahartanto@yahoo.com ${ }^{1}$,try_uns@yahoo.com², nana_adenensi@yahoo.co.id ${ }^{3}$, y_ariana@yahoo.com ${ }^{4}$
}

\begin{abstract}
Science and technology have progressed very rapidly. Progress most felt touches people's lives today one of which is progress in the field of communication and information technology. The rapid development of science and technology, brings lifestyle changes in fostering close relationships with others. The way they communicate the most often is to use social networking. Social networks as a means of communicating in cyberspace, connecting or establishing verbal communication through a set of computers or the like that are connected through a telecommunications network. One of them is Facebook, which is ranked first. The majority of internet users are women. Most women internet users come from professionals and are followed by housewives who use the internet and information technology to help their productivity. Female internet users in Indonesia are dominated by big city residents even though the distribution of users is already widespread. Given the large number of women who have social media, literacy is needed about how to do good and right social media so as to keep women away from various problems as a result of using the wrong social media.
\end{abstract}

Keywords: women, social media.

\begin{abstract}
Abstrak
Ilmu pengetahuan dan teknologi telah mengalami kemajuan yang sangat pesat. Kemajuan yang paling banyak dirasakan menyentuh kehidupan masyarakat saat ini salah satunya adalah kemajuan dalam bidang teknologi komunikasi dan informasi. Perkembangan IPTEK yang begitu pesat, telah membawa perubahan gaya hidup dalam membina hubungan akrab dengan orang lain. Cara berkomunikasi yang paling sering mereka gunakan adalah dengan menggunakan jejaring sosial. Jejaring sosial sebagai salah satu sarana berkomunikasi dalam bentuk maya, berhubungan atau menjalin komunikasi secara verbal melalui seperangkat komputer atau sejenisnya yang dihubungkan melalui suatu jaringan telekomunikasi. Salah satunya ialah facebook yang menempati peringkat pertama. Mayoritas pengguna internet adalah kaum perempuan. Perempuan pengguna internet paling banyak berasal dari kalangan profesional dan diikuti ibu rumah tangga yang memanfaatkan internet dan teknologi informasi untuk membantu produktivitas mereka. Perempuan pengguna internet di Indonesia didominasi penduduk kota besar meskipun sebaran penggunanya sudah meluas. Mengingat besarnya jumlah perempuan yang bermedia sosial, maka dibutuhkan civic literasi tentang bagaimana bermedia sosial yang baik dan benar sehingga menjauhkan perempuan dari berbagai masalah sebagai akibat pengunaan media sosial yang salah.
\end{abstract}

Kata Kunci: perempuan, media sosial 


\section{Pendahuluan}

Era globalisasi ditandai dengan pesatnya kemajuan teknologi khususnya di bidang informasi dan komunikasi. Salah satu teknologi komunikasi yang sangat berkembang pesat saat ini adalah internet. Internet telah menjadi salah satu faktor penting dalam perkembangan pengetahuan manusia, relasi antar manusia, aktivitas bisnis dan lain sebagainya sehingga menjadikan internet sangat penting bagi penggunanya dalam kehidupan sehari-hari.

Perkembangan internet yang sangat pesat saat ini telah memberikan dampak yang sangat signifikan terhadap perubahan masyarakat atau penggunanya. Keberadaan internet juga telah mempengaruhi kehidupan kaum perempuan karena data yang menunjukkan bahwa perempuan sangat aktif dalam menggunakan internet dalam kehidupan sehari-hari dengan menggunakan media sosial termasuk di Indonesia. Penggunaan internet untuk mengakses media sosial oleh kaum perempuan di Indonesia mencapai 79,92\%.

Media sosial adalah sekumpulan aplikasi berbasis internet, beralaskan pada ideologi dan teknologi Web 2.0 sehingga memungkinkan penciptaan dan pertukaran konten oleh penggunanya (Kaplan \& Haenlein, 2010). Permasalahan yang timbul pada penggunaan media sosial antara lain berupa peleburan ruang privat dengan ruang publik para penggunanya. Hal ini mengakibatkan pergeseran budaya berupa pengguna tak lagi segan mengupload segala kegiatan pribadinya untuk disampaikan kepada teman atau kolega melalui akun media sosial dalam membentuk identitas diri mereka (Ayun PQ, 2015). Penggunaan media sosial juga dapat menyebabkan ketergantungan/ adiksi yang berdampak buruk. Salah satunya adalah hubungan antara penggunaan Facebook dengan menurunnya kualitas tidur (Wolniczak et al., 2013). Suatu studi pilot oleh Szczegielniak A (2013) juga menunjukkan hal yang serupa, bahkan penggunaan media sosial juga dihubungkan dengan depresi dan anxietas (Pantic at al., 2012, Koc \& Gulyagci, 2013). Kebanyakan pengguna media sosial yang terkena imbas buruk ini adalah perempuan, karena suatu studi oleh Duggan \& Brenner (2013) menyatakan bahwa perempuan lebih aktif pada media sosial dibanding laki-laki dan kehidupannya banyak dipengaruhi oleh media sosial. Imbas negatif lain dinyatakan oleh Ibrahim (2011) yaitu, generasi yang tumbuh dalam budaya digital memiliki kecenderungan bersifat menyendiri (desosialisasi). Masalah yang tak kalah pelik adalah penyebaran berita hoax, hate crime (cyberhate), dan cyber-bullying yang semakin meningkat (William M \& Pearson O, 2016).

Dilihat dari sisi sebaliknya, media sosial juga menawarkan berbagai manfaat. Suatu studi di Korea oleh Khan GF, et al (2013) mengenai risiko vs keuntungan (risk vs benefit) dari media sosial. Faktor risiko berupa risiko sosial, risiko psikologis, dan masalah privacy. Sedangkan keuntungan berupa konektivitas sosial, keterlibatan sosial, update informasi dan hiburan. Studi ini menyimpulkan bahwa efek keuntungan atau benefit dirasakan oleh pengguna lebih besar dibanding risikonya.

Mengingat besarnya jumlah perempuan yang bermedia sosial, maka dibutuhkan literacy media tentang bagaimana bermedia sosial yang baik dan benar sehingga menjauhkan perempuan dari berbagai masalah sebagai akibat pengunaan media sosial yang salah..

\section{Pelaksanaan Dan Metode}

Pengabdian pada Masyarakat ini untuk merespons adanya kenyataan banyaknya jumlah perempuan pengguna media sosial dan kebutuhan adanya literacy bermedia sosial yang baik dan benar di kalangan perempuan sehingga penggunaan media sosial dapat berkontribusi positif bagi perempuan.

Manfaat dari Pengabdian pada Masyarakat ini adalah terjaganya kesinambungan fungsi Tri Darma Perguruan 
Tinggi, yaitu fungsi pendidikan, penelitian, dan pengabdian masyarakat. Bagi perempuan Pengabdian pada Masyarakat (IbM) ini bermanfaat untuk meningkatkan pengetahuan dan kesadaran tentang pentingnya bermedia sosial yang baik dan benar sehingga mereka dapat terhindar dari masalah dalam bermedia sosial.

Pengabdian pada Masyarakat ini menggunakan metode pendidikan masyarakat yang dilakukan dengan cara penyuluhan yang bertujuan untuk meningkatkan pemahaman masyarakat sasaran yaitu perempuan terhadap literasi media sosial. Langkah-langkah kegiatan mencakup 3 (tiga) tahap yaitu perencanaan, pelaksanaan, dan evaluasi. Pada tahap perencanaan, Tim pelaksana bersama beberapa Pengurus PKK Kecamatan Banjarsari, Kota Surakarta mengadakan pertemuan untuk membicarakan teknis pelaksanaan. Hal yang dibicarakan adalah penetapan tempat dan tanggal pelaksanaan kegiatan, penataan acara, undangan, konsumsi dan materi pembicaraan. Pada tahap pelaksanaan ini dilaksanakan penyuluhan sedangkan pada tahap evaluasi dilaksanakan setelah selesainya kegiatan Pengabdian kepada Masyarakat ini selesai dilaksanakan.

\section{Hasil dan Pembahasan}

Survey yang dilakukan oleh Asosiasi Penyelenggara Jasa Internet Indonesia (APJII) pada tahun 2018 menyebutkan bahwa pengguna internet di Indonesia tahun 2018 adalah 171,17 juta jiwa dari total populasi penduduk Indonesia sebesar 264,16 juta jiwa atau 64, 8\%. Dari angka tersebut, 95 persennya menggunakan internet untuk mengakses jejaring sosial. Generasi muda dalam rentang usia 15-19 tahun dan 20-24 tahun memiliki angka penetrasi lebih dari 88 persen pengguna internet di Indonesia.

Media sosial mendominasi konten internet sebagai yang paling sering diakses oleh netizen. Tercatat 97, 4 persen orang Indonesia mengakses akun media sosial saat menggunakan internet. Sedangkan konten media sosial yang paling sering dikunjungi adalah Facebook (50,7\%), Instagram $(17,8 \%)$, Youtube $(15,1 \%)$.

Dari sisi pertambahan jumlah pengguna di layanan media sosial, Indonesia menempati posisi ketiga di dunia setelah Cina dan India. Khusus pengguna Facebook, salah satu perusahaan riset dunia yaitu We Are Social, menyatakan bahwa Indonesia masih menempati posisi keempat dalam daftar negara dengan pengguna Facebook terbanyak, hanya kalah dari Amerika Serikat, India, dan Brazil.

Penggunaan internet untuk mengakses media sosial oleh kaum perempuan di Indonesia mencapai 79,92\%.

Samovar LA \& Porter RE (2009) mengatakan bahwa media sosial dapat mengakibatkan perubahan pada 6 (enam) unsur budaya :

a. Media sosial membawa perubahan pada kepercayaan (belief), nilai (values), dan sikap (attitudes).

Dengan media sosial, masalah hubungan seseorang dengan Sang Pencipta tidak lagi dianggap sebagai hubungan individual, tetapi kelompok. Seseorang dapat berbagi pengalaman rohaninya atau ucapan rasa syukur terhadap Pencipta dengan orang lain maupun kelompok misalnya dengan menggunakan Facebook atau Twitter. Media sosial juga dapat mengubah nilainilai dalam masyarakat, misalnya budaya masyarakat Indonesia dikenal dengan budaya sopan santun. Dengan media sosial, terjadi pergeseran nilai karena seseorang dapat memberi kritik tajam, hujatan, bahkan makian secara langsung terhadap individu atau kelompok lain tanpa memikirkan konsekuensi pada sang terhujat. Media sosial juga menyebabkan perubahan sikap pada masyarakat. Salah satu contohnya adalah seseorang tak lagi menganggap pertemuan langsung atau silaturahmi sebagai sesuatu yang penting, karena dapat dilakukan hanya dengan chatting di media sosial. Sikap 
acuh tak acuh dan tidak peduli pada lingkungan sekitar juga merupakan dampak dari penggunaan media sosial yang banyak ditemukan.

b. Pandangan dunia (worldview)

Cara pandang sempit (tradisional) yang berubah menjadi cara pandang global (modern). Hal inilah yang sering mengakibatkan geger budaya. Sebagai contoh gaya berpacaran remaja di luar negeri yang cenderung bebas dan diupload pada Facebook atau media sosial lainnya, telah banyak diterapkan oleh remaja Indonesia, walaupun sebenarnya sangat bertentangan dengan budaya sekitar.

c. Organisasi sosial

Organisasi sosial yang dibentuk di media sosial seperti Facebook tidak lagi bersifat resmi dan terikat seperti di dunia nyata. Seorang anggota organisasi sosial di Facebook dapat sangat aktif maupun pasif, tidak ada keterikatan dan rasa tanggung jawab seperti pada dunia nyata. Tetapi justru hal inilah yang membuat sebagian besar masyarakat merasa tertarik untuk bergabung dengan organisasi pada media sosial.

d. Tabiat manusia (human nature)

Status pada Facebook maupun media sosial lain sering menunjukkan tabiat narsis, egosentris, ingin merasa lebih dari yang lain dan ingin menonjolkan kelebihan diri sendiri. Banyak juga yang terlihat berusaha membuka kekurangan dan memojokkan orang lain. Tabiat buruk yang dahulu ditutupi, sekarang jelas terpampang pada media sosial seseorang dengan atau tanpa disadari oleh pemilik akun tersebut.

e. Orientasi kegiatan (activity orientation) Orientasi kegiatan yang bersifat positif antara lain mengupload kegiatan untuk tujuan bisnis, perdagangan atau kegiatan sosial. Orientasi kegiatan yang bersifat negatif antara lain mengupload suatu kegiatan dengan tujuan pamer, atau membangun citra diri.

f. Persepsi tentang diri sendiri dan orang lain (perseption on self and others)
Perilaku pengguna Facebook yang berusaha membangun konsep diri mereka sendiri dengan menuliskan status pada laman Facebook mereka. Mengekspos diri sendiri untuk mendapat perhatian orang lain, misalnya dengan mengunduh (upload) foto untuk berlomba mendapatkan "like" dari orang lain.

Tahapan penyuluhan dalam rangka pengabdian pada masyarakat literacy bermedia sosial bagi perempuan yang tergabung dalam PKK Kecamatan Banjarsari, Kota Surakarta ini meliputi :

\section{Pemaparan Materi}

Materi dipaparkan berkenaan dengan apa itu media sosial, ciri-ciri media sosial, kegunaan media sosial dan etika bermedia sosial. Etika bermedia sosial yang disampaikan dalam penyuluhan ini adalah sebagai berikut :

\section{a. Prinsip}

THINK (Is It True, Is It Helpfull, Is It Illegal, Is It Nesessary, Is It Kind) adalah prinsip dasar yang sederhana untuk membantu menggunakan media sosial dengan bijak.

- Is It True : Apakah informasi atau konten yang diunggah atau akan dibagi adalah benar?

Banyak informasi yang beredar merupakan hoax (bohong) atau sudah disunting oleh banyak tangan. Kita harus mampu menelaah kebenaran isi media sosial. Misalnya dengan membiasakan mengecek ke beberapa sumber berbeda yang terpercaya: situs berita, ensiklopedi, atau bertanya langsung kepada sumbernya. Kita juga sebaiknya tidak mudah untuk menerima permintaan pertemanan dari orang-orang yang tidak kita kenal, bahkan ketika memiliki mutual friend. Tidak semua profil dapat dipercaya! 
Is It Helpfull : Teknologi hendaknya digunakan untuk kebaikan dan bermanfaat bagi orang lain. Ketika kita mengunggah sebuah informasi, foto atau video, mari kita pikirkan apakah materi tersebut bermanfaat dan mungkin dapat menolong teman dan keluarga kita yang menerimanya.

- Is It Illegal : Sadari adanya hak cipta. Ketika kita akan memuat atau membagi tulisan atau foto, tanyakan kembali: Apakah si empunya sudah setuju? Biasakan diri untuk menuliskan sumber materi yang ingin diunggah ke media sosial. Misalnya: kredit foto: (nama empunya/sumber), sumber (nama situs/buku/penulis). Mintalah izin di media sosial dengan cara menulis di komentar atau mengirimkan pesan pribadi.

Ketahui juga bahwa ada yang dikategorikan termasuk dalam konten illegal atau melawan hukum, contohnya konten yang mengandung pornografi, ujaran kebencian, penipuan hingga ancaman atau intimidasi.

- Is It Nesessary : Kita biasanya memiliki kecenderungan berbagi semua hal di media sosial. Ke mana kita pergi, apa yang kita pikirkan, sampai terkadang tidak sadar ingin berbagi sesuatu yang bersifat pribadi. Mari kita berpikir lagi, sedemikian perlukah kita mengunggah konten tersebut? Buatlah skala prioritas. Perlukah konten tersebut dimuat? Dari skala 1 10, di manakah posisi konten ini? Jika kurang dari 5, mari pikirkan ulang keputusannya.

Ingatlah selalu, bahwa apapun yang diunggah ke media sosial akan tetap berada di sana. Jejak digital akan selalu tercatat dan dapat ditelusuri dengan mudah.

Is It Kind : Hal utama yang penting untuk kita ingat adalah untuk selalu mengunggah hal-hal yang tidak jahat. Apa gunanya kita mempostikan konten yang hanya akhirnya hanya mencederai perasaan orang lain? Tidak hanya konten berupa teks, tetapi juga foto dan video. Mari kita saling menghormati dan menghargai keberadaan netizen lain. Hidup terlalu pendek untuk kita habiskan saling menyakiti.

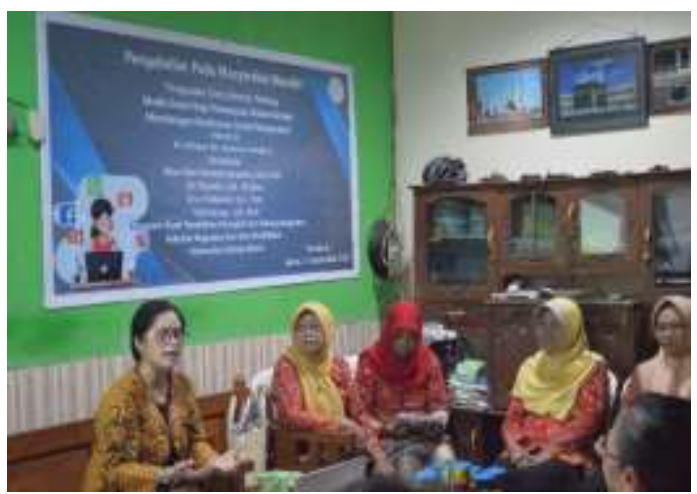

Gambar 1. Pemaparan Materi Penyuluhan

b. Panduan Dasar

Sedangkan 5 (lima) panduan dasar dalam menggunakan media sosial :

- Menjaga Privasi : Tidak dengan mudah memberikan informasi data diri di sosial media.

- Jaga Keamanan Akun : Membuat kata kunci yang cukup sulit untuk ditebak dan mengubahnya secara berkala.

- Menghindari Hoax : Tidak mudah percaya dengan berita yang diterima sebelum melakukan klarifikasi.

- Menyebarkan Hal yang Positif: Tetaplah menyebarkan informasi-informasi positif, sekalipun di media sosial yang sifatnya eksklusif.

- Gunakan Seperlunya : Tetap gunakan media sosial untuk membantu meningkatkan produktifitas diri dan sadari diri 
jika telah mengalami ketergantungan.

c. Hukum dan Perundang-undangan Dalam Bermedia Sosial

Undang-Undang Nomor 11 Tahun 2008 tentang Undang-Undang Informasi dan Transaksi Elektronik (UU ITE) adalah undang-undang yang mengatur tentang informasi dan transaksi elektronik, atau teknologi informasi secara umum. Yurisdikasi undang-undang ini berlaku untuk setiap orang yang melakukan perbuatan hukum sebagaimana diatur dalam undangundang tersebut, baik mereka yang berada di wilayah hukum Indonesia maupun di luar wilayah hukum Indonesia, yang memiliki akibat hukum di Indonesia dan/atau di luar wilayah hukum Indonesia dan merugikan kepentingan Indonesia. UU ITE dibagi menjadi 2 (dua) bagian besar, yaitu pengaturan mengenai informasi dan transaksi elektronik dan pengaturan mengenai perbuatan yang dilarang. Berikut sekilas pasal-pasal yang mengatur kasus dalam UU ITE :

$>$ Perbuatan yang dilarang (cybercrime) diuraikan pada Bab VII (Pasal 27-37) :

Pasal 27 (asusila, perjudian, penghinaan, dan pemerasan)

Pasal 28 (berita bohong dan menyesatkan, berita kebencian dan permusuhan)

Pasal 29 (ancaman kekerasan dan menakut-nakuti)

Pasal 30 (akses komputer pihak lain tanpa izin)

Pasal 31 (penyadapan, perubahan, penghilangan informasi)

Pasal 32 (pemindahan, perusakan, dan membuka informasi rahasia)

Pasal 33 (virus, membuat sistem tidak dapat bekerja)

Pasal 35 (menjadikan seolah dokumen otentik)

\section{Latihan}

Latihan diberikan kepada peserta dalam rangka tindak lanjut dari materi yang telah disampaikan. Salah satu bentuk latihan yang dilakukan adalah untuk membedakan sebuah berita merupakan hoax atau tidak yaitu dengan langkahlangkah sebagai berikut :

a. Baca berita hanya dari sumber yang layak dipercaya dan kredibel

b. Baca dulu isi beritanya, baru share (bagi) ke media sosial (facebook, twitter, WA, dan sebagainya). Banyak orang yang hanya setelah membaca judul dan gambarnya, langsung menyebarkan berita tersebut ke media sosial tanpa mengetahui dan memahami isi berita

c. Lihat alamat situs. Bila mendapat informasi hoax berupa pemberitaan berita, perhatikan nama media yang membuat berita sekaligus alamat situs

d. Cek fakta. Perhatikan narasumber yang dicantumkan pada berita tersebut, apakah berasal dari sumber resmi/kredibel atau tidak. Bedakan juga antara fakta dan opini. Fakta merupakan peristiwa yag terjadi dan memiliki bukti, sedangkan opini adalah pendapat atau kesan dari penulis

e. Jangan menelan mentah-mentah semua informasi dari internet. Pelajari terlebih dahulu semua informasi dari internet tersebut, lakukan cross check dengan membaca informasi tersebut dari sumber lain

f. Jangan mudah terprovokasi



Gambar 2. Antusiasme peserta dalam sesi latihan 


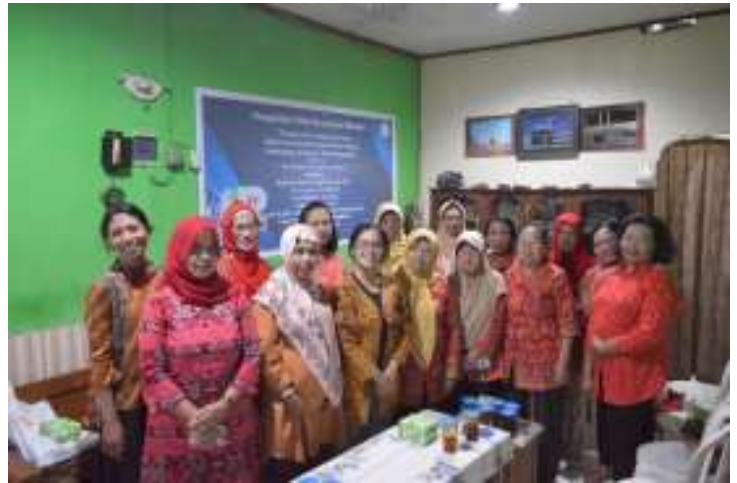

Gambar 3. Tim Pengabdi bersama beberapa peserta pengabdian

\section{Penutup}

\section{Simpulan}

Mengingat bahwa aktivitas perempuan sangat dominan dalam bermedia sosial, maka perempuan perlu memperhatikan beberapa hal yang dapat dilakukan dalam menghindari permasalahan yang muncul dari pemanfaatan media sosial yaitu dengan proteksi informasi pribadi, etika dalam berkomunikasi, hindari penyebaran SARA dan pornografi, memandang penting hasil karya orang lain, membaca berita secara keseluruhan, jangan hanya menilai dari judulnya, dan kroscek kebenaran berita atau informasi.

Dalam media sosial, konten yang bersifat pribadi dapat menjadi milik publik. Oleh karena itu harus digunakan secara bijak untuk menghindari hal-hal yang tidak diinginkan. Setiap individu pengguna dari media sosial seharusnya memiliki kesadaran pribadi, bahwa apapun yang diunggah ke dalam media sosial selain dapat mempengaruhi citra diri sendiri, juga dapat mempengaruhi hubungan sosial dengan pihak lain. Keluasan informasi hendaklah dipilah dengan bijaksana, mana saja yang dapat digunakan dengan baik tanpa melanggar norma dan nilai-nilai yang berlaku dalam kehidupan sosial. Kebebasan berekspresi harus tetap berpegang pada etika komunikasi dan pengendalian diri yang baik.

\section{Saran}

Studi ini memperlihatkan bahwa perempuan memiliki peran penting membangun ketahanan sosial masyarakat dengan cara bermedia sosial dengan baik dan benar, oleh sebab itu pengetahuan dan kesadaran tentang media sosial perlu diperkuat lagi.

\section{Daftar Pustaka}

Ayun PQ. (2015). Fenomena remaja menggunakan media sosial dalam membentuk identitas. Channel, 3(2), 1-16.

Duggan M. Brenner J. (2013). Report, The Demographics of Social Media Users 2012. Pew Internet \& American Life Project, Washington DC.

Ibrahim, Subandy I. (2011). Kritik Budaya Komunikasi. Jalasutra, Yogyakarta.

Kaplan AM, Haenlein M. (2010). Users of the world, unite! The challenges and opportunities of Social Media. Business Horizons , 53, 59-68.

Pantic I, Damjanovic A, Todorovic J, Topalovic D, Bojovic- Jovic D, Ristic S et al. (2012). Association between online social networking and depression in high school students: behavioral physiology viewpoint. Psychiatr Danubia, 24, 90-3.

Samovar LA, Porter RE, McDaniel ER. (2010). Communication Between Cultures. Cengage Learning, America.

Szczegielniak A. Pałka K, Krysta K.(2013). Problems Associated With The Use Of Social Networks - A Pilot Study. Psychiatria Danubina, 25(2), 212-15.

William M, Pearson O. (2016). Hate Crime and Bullying in the Age of Social Media- Conference Report. Cardiff University, England. 
Wolniczak I, Cáceres-DelAguila JA,

Palma-Ardiles G, Arroyo KJ, Solís-

Visscher R, Paredes- Yauri $S$ et al. (2013). Association between Facebook dependence and poor sleep quality: a study in a sample of undergraduate students in Peru. PLoS One., 8:e59087. 